\title{
Three-Dimensional Geologic Framework Modeling of Faulted Hydrostratigraphic Units within the Edwards Aquifer, Northern Bexar County, Texas
}

By Michael P. Pantea and James C. Cole

Scientific Investigations Report 2004-5226 


\section{U.S. Department of the Interior \\ Gale A. Norton, Secretary \\ U.S. Geological Survey \\ Charles G. Groat, Director}

U.S. Geological Survey, Reston, Virginia: 2004

For more information about the USGS and its products:

Telephone: 1-888-ASK-USGS

World Wide Web: http://www.usgs.gov/

This product is available on the Web at http://pubs.usgs.gov/sir/2004/5226

Any use of trade, product, or firm names in this publication is for descriptive purposes only and does not imply endorsement by the U.S. Government.

Although this report is in the public domain, permission must be secured from the individual copyright owners to reproduce any copyrighted materials contained within this report. 


\section{Contents}

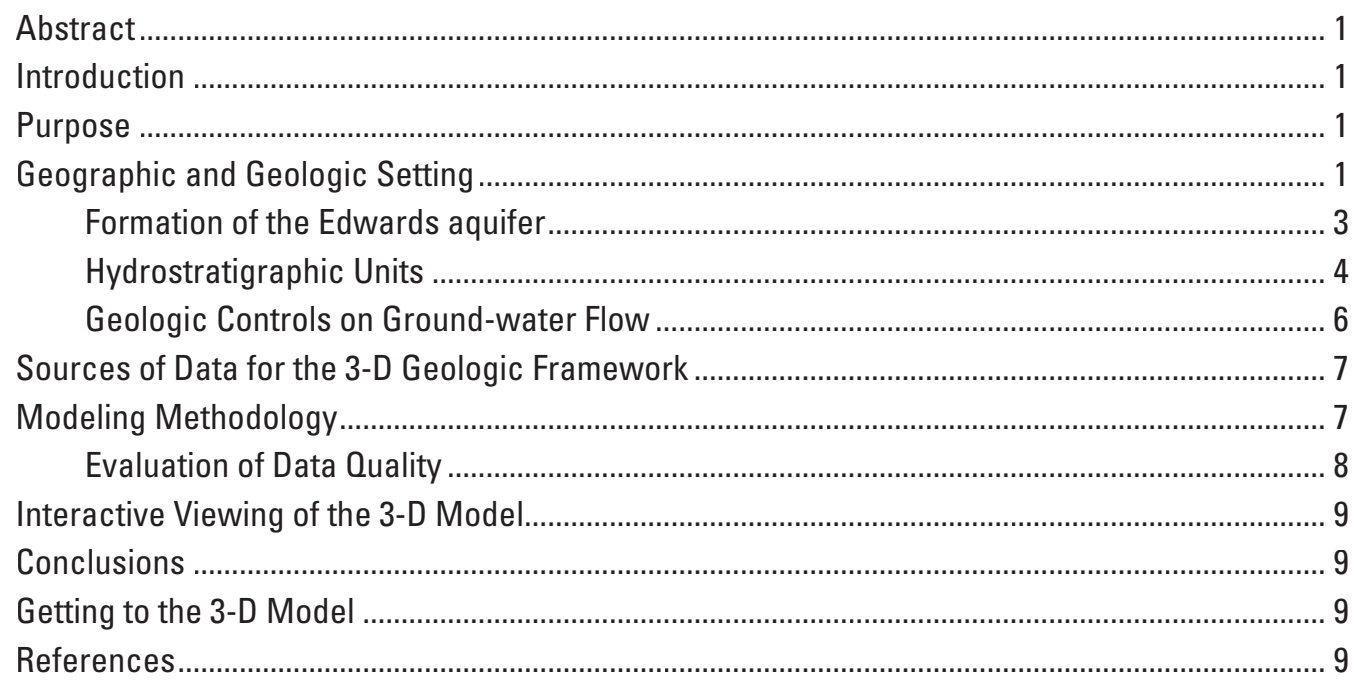

\section{Tables}

1. Characteristics of Edwards Group Hydrostratigraphic units

\section{Figures}

1. Sketch map showing location of the geologic model area.

2. Vertical view of top of the geologic model showing model distribution of hydrostratigraphic units of the Edwards aquifer..

3. Vertical view of the top of the geologic model showing traces of selected strands of the Balcones fault zone.

4. Overview perspective across the 3-D geologic model showing distribution of control points 


\title{
Three-Dimensional Geologic Framework Modeling of Faulted Hydrostratigraphic Units within the Edwards Aquifer, Northern Bexar County, Texas
}

\author{
By Michael P. Pantea and James C. Cole
}

\section{Abstract}

This report describes a digital, three-dimensional faulted hydrostratigraphic model constructed to represent the geologic framework of the Edwards aquifer system in the area of San Antonio, northern Bexar County, Texas. The model is based on mapped geologic relationships that reflect the complex structures of the Balcones fault zone, detailed lithologic descriptions and interpretations of about 40 principal wells (and qualified data from numerous other wells), and a conceptual model of the gross geometry of the Edwards Group units derived from prior interpretations of depositional environments and paleogeography.

The digital model depicts the complicated intersections of numerous major and minor faults in the subsurface, as well as their individual and collective impacts on the continuity of the aquifer-forming units of the Edwards Group and the Georgetown Formation. The model allows for detailed examination of the extent of fault dislocation from place to place, and thus the extent to which the effective cross-sectional area of the aquifer is reduced by faulting. The model also depicts the internal hydrostratigraphic subdivisions of the Edwards aquifer, consisting of three major and eight subsidiary hydrogeologic units.

This geologic framework model is useful for visualizing the geologic structures within the Balcones fault zone and the interactions of en-echelon fault strands and flexed connecting fault-relay ramps. The model also aids in visualizing the lateral connections between hydrostratigraphic units of relatively high and low permeability across the fault strands.

\section{Introduction}

The Edwards aquifer is the principal source of water for municipal, agricultural, industrial, and military uses by nearly 1.5 million inhabitants of the greater San Antonio, Texas, region (Hovorka and others, 1996; Sharp and Banner, 1997). Discharges from the Edwards aquifer also support local recreation and tourism industries at Barton, Comal, and San Marcos Springs located northeast of San Antonio (Barker and others, 1994), as well as base flow for agricultural applications farther downstream. Average annual discharge from large springs (Comal, San Marcos, Hueco, and others) from the Edwards aquifer was about 365,000 acre-ft from 1934 to 1998, with sizeable fluctuations related to annual variations in rainfall. Withdrawals through pumping have increased steadily from about 250,000 acre-ft during the 1960 's to over 400,000 acre$\mathrm{ft}$ in the 1990's in response to population growth, especially in the San Antonio metropolitan area (Slattery and Brown, 1999). Average annual recharge to the system (determined through stream gaging) has also varied considerably with annual rainfall fluctuations, but has been about 635,000 acre-ft over the last several decades.

\section{Purpose}

This paper describes the data and processes used to construct a digital three-dimensional (3-D) model of the Edwards aquifer for an area of northern Bexar County (fig. 1). Our primary goal was to use sophisticated geologic modeling software (EarthVision ${ }^{\mathrm{TM}}$; Dynamic Graphics, Inc., Alameda, CA) to accurately represent the faulted lithologic units that make up the hydrogeologic framework in this area. This model allows us to view and evaluate the overall shape and form of the aquifer in this region, and to assess the amount of dislocation of the aquifer across the many strands of the Balcones fault zone.

A secondary purpose of this report is to examine the functionality and feasibility of an interactive 3-D model viewer that allows each user considerable graphic capability to manipulate and explore the 3-D model on a choice of computer platform. This report package includes the fully functional 3-D viewer, the data files used to generate the hydrostratigraphic model, a tutorial help file to explain the 3-D viewer functions, and ancillary materials for the modeling project.

\section{Geographic and Geologic Setting}

The Edwards aquifer consists of rocks of the Lower Cretaceous Edwards Group and Georgetown Formation that are exposed along the Balcones fault escarpment, which marks 
Figure 1. Sketch map showing location of the geologic model area in relation to Bexar County and the general outline of the San Antonio, Texas, metropolitan area. The recharge zone for the Edwards aquifer system is indicated by the yellow shaded area, which marks the outcrop belt of tilted, faulted strata of the Edwards Group and the overlying Georgetown Formation. Blue box outlines the areal extent of the 3-D model.

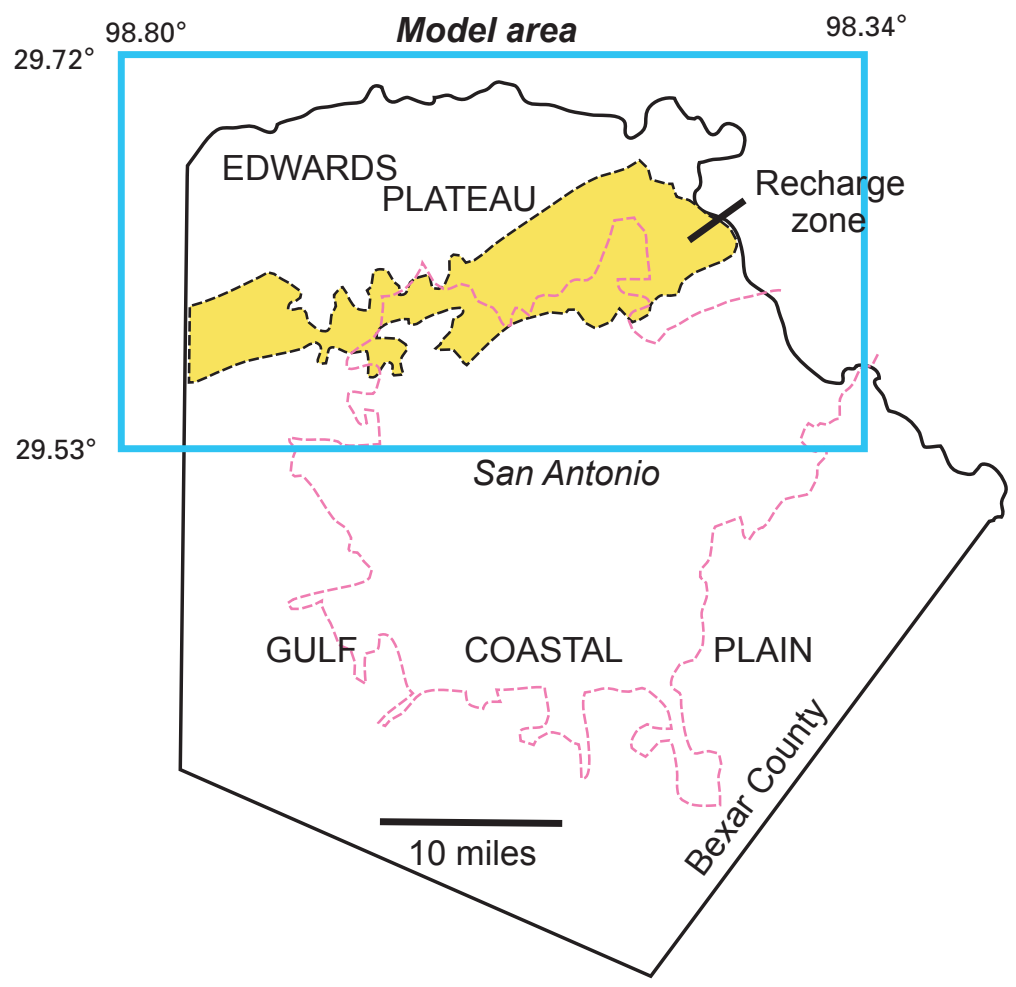

The Edwards Group is typically 430-500 ft thick (130$155 \mathrm{~m}$ ) where it is completely preserved in the subsurface of central Bexar County (Stein and Ozuna, 1996). The Group consists of the Kainer Formation (260-310 ft thick; 80-95 m) in its lower part and the Person Formation (170-200 ft thick; $50-65 \mathrm{~m}$ ) in its upper part. These two formations represent two major transgressive-regressive cycles related to sea-level change and epeirogenic deformation (Barker and others, 1994; Stein and Ozuna, 1996; Hovorka, 1996). Lithologic units within these formations consist of argillaceous wackestone and packstone at the base, packstone and grainstone in the middle, and argillaceous tidal-flat mudstone and evaporite rocks in the upper parts. Lateral and vertical variation in depositional lithology is commonplace, but the dense, argillaceous wackestone units at the bases of both formations are conspicuous in both outcrop and in subsurface wells and can be correlated across the area.

The Edwards Group was partly exposed and eroded in late Albian time (late Early Cretaceous) due to sea-level drop and flexural uplift of the San Marcos Platform (Maclay and Small, 1986; Barker and others, 1994). As much as $100 \mathrm{ft}$ (30 m) of section was locally removed from the Edwards, and dissolution, karst collapse, and diagenetic alteration developed over a widespread area in the southeast part of the model area in this study. Limestone of the Georgetown Formation, which lies disconformably on the Edwards Group, records renewed marine transgression in early Cenomanian time. Post-Georgetown erosion occurred during subsequent renewed uplift of the platform. Significant sea-level rise a few million years later led to deposition of the Del Rio Clay across the entire platform area, and the Del Rio forms the base of the regional upper confining unit over the Edwards aquifer (Barker and others, 1994). marine basin to the south and east (Barker and others, 1994). 


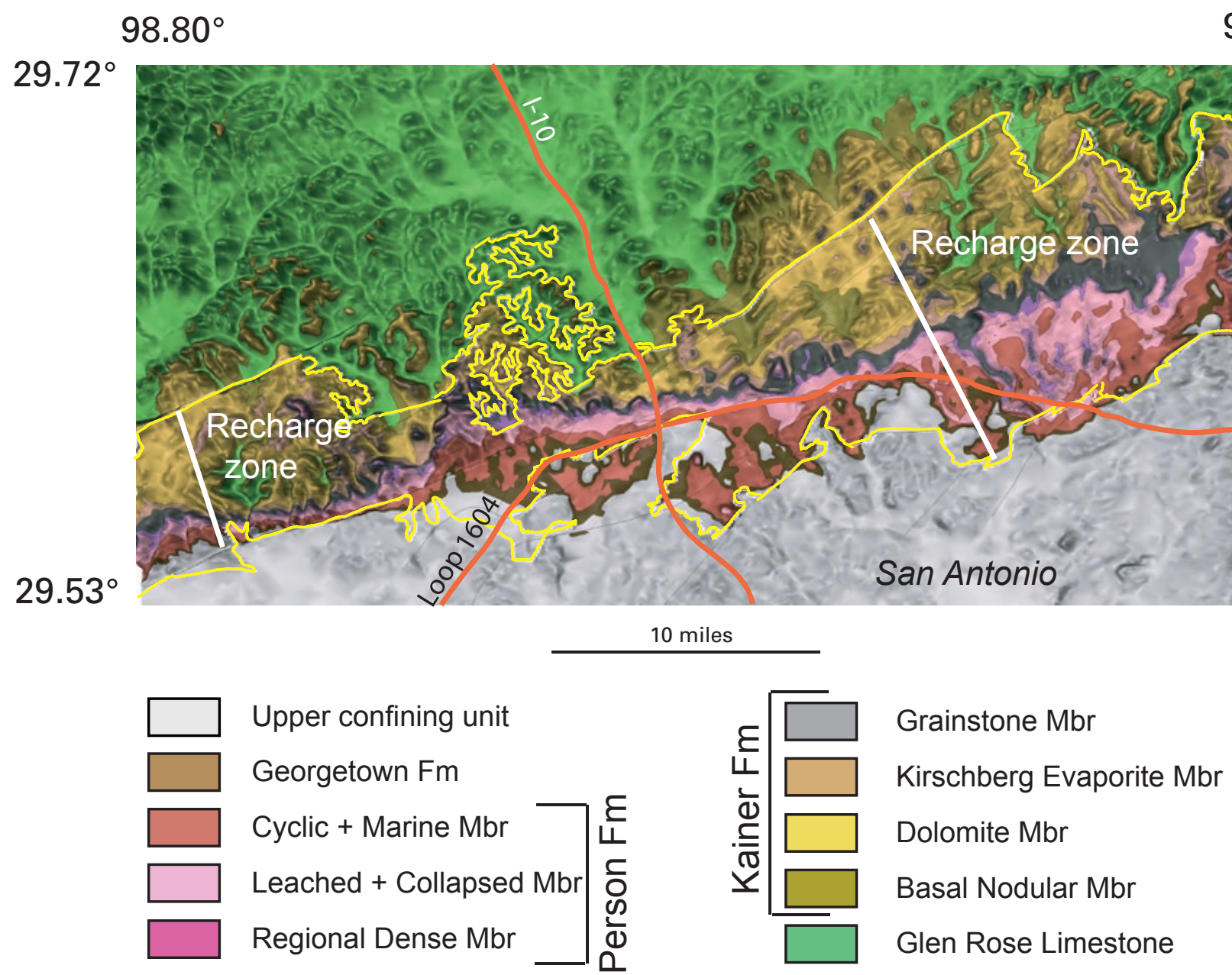

Figure 2. Vertical view of the top of the geologic model area showing Edwards Group and enclosing units; shaded texture reflects the modeled topography based on 30-m Digital Elevation Model data from the U.S. Geological Survey. The yellow outline of the recharge zone is based on detailed geologic mapping by Stein and Ozuna (1996). Correspondence of the 3-D geologic model to this mapping is indicated by the generally close agreement between the mapped outline and the modeled distribution of Edwards aquifer units (exposed between the Glen Rose Limestone and upper Confining unit).

\section{Formation of the Edwards Aquifer}

The carbonate and evaporitic strata of the Edwards Group and Georgetown Formation show widespread evidence of complex alteration, recrystallization, dissolution, and cementation. These processes, singly and in combination, profoundly affected the porosity and permeability structure of the original depositional units and collectively produced the lithologic framework of the present-day Edwards aquifer (Maclay and Small, 1986; Hovorka and others, 1996). The details of these processes are beyond the scope of this report, but they are well summarized and discussed in reports by Hovorka and others (1996, 1998) and by Maclay (1995).

Two significant events are recognized as the principal contributors to formation of the karst aquifer system in the Edwards. The first event was uplift of the San Marcos Platform in latest Albian (late Early Cretaceous) time, which led to local erosion, dissolution by meteoric water, and karst formation. The second event dates to the Miocene and younger uplift of the Edwards Plateau along the Balcones fault zone (Barker and others, 1994). This Cenozoic uplift produced more than $1,000 \mathrm{ft}(300 \mathrm{~m})$ of differential displacement and led to widespread stripping of the post-Lower Cretaceous strata from the Edwards and Trinity Groups. In the process, the uplifted Edwards Group beds were exposed to meteoric-water circulation, which leached significant volumes of evaporite minerals and dolomite (Maclay and Small, 1986).

The formation of high-permeability zones took place over millions of years and was localized in the Balcones fault zone. Leaching and dissolution of the dolomitic and evaporitic components did not occur in the southern, down-thrown blocks of the Balcones fault zone (Maclay and Small, 1986). In this part of the system, the Edwards Group and Georgetown Formation remain dolomitic and retain bedded evaporite deposits 


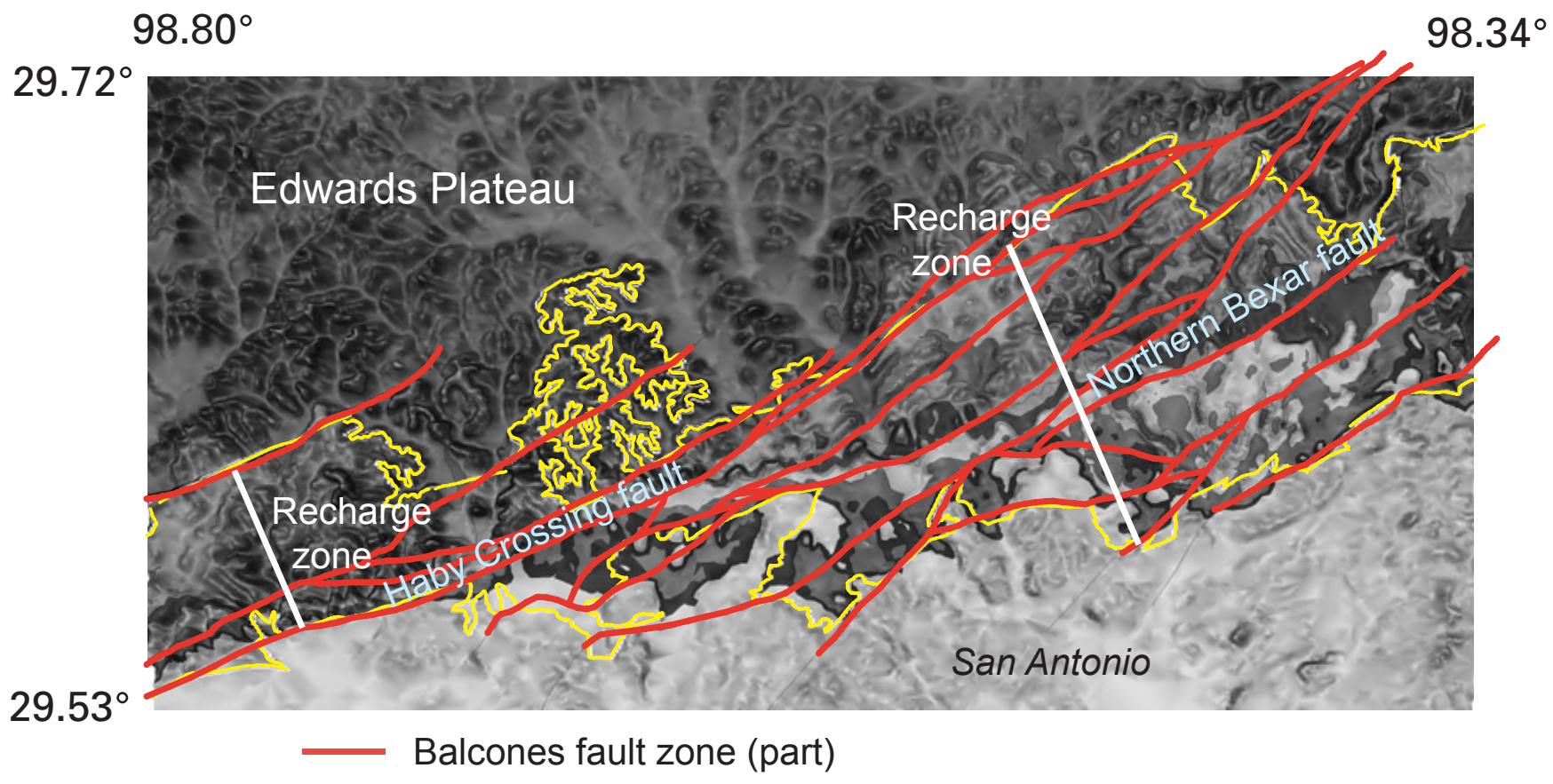

10 miles

Figure 3. Vertical view of the top of the geologic model area showing selected strands of the Balcones fault zone incorporated in the geologic model. Most faults show normal, down-to-the-south displacement. Yellow outline of the recharge zone is shown for reference. Background is the same as figure 2, but converted to grayscale tones.

(Maclay and Small, 1986). Interstitial formation water is moderately to strongly saline compared to the fresh-water zone, and it is particularly enriched in chloride and sulfate anions. The practical down-dip limit of potable water in the Edwards aquifer system is marked by the arbitrarily defined limit of 1,000 ppm total-dissolved-solids (Maclay and Small, 1986; Schultz, 1994).

\section{Hydrostratigraphic Units}

Subsurface studies of the Edwards Group and aquifer by Rose (1972), and amplified by Maclay and others in the late 1970's (see Maclay and Small, 1986), identified subunits of the Kainer and Person Formations that seemed to have hydrostratigraphic distinction and lateral continuity through Bexar County and surrounding areas (table 1). From base to top of the Kainer Formation, these units comprise the basal nodular member, the dolomitic member, the Kirschberg Evaporite Member, and the grainstone member. Ascending units of the Person Formation comprise the regional dense member, the combined leached and collapsed members, and the combined cyclic and marine members. The overlying, disconformable Georgetown Formation is included in the definition of the Edwards aquifer because it is hydrologically connected to the Edwards Group. These hydrostratigraphic units of the Kainer, Person, and Georgetown Formations are the units modeled in three-dimensions in this report. These same units were mapped across the land surface of Bexar County by Stein and Ozuna (1996).
The hydrostratigraphic sub-units of the Kainer and Person Formations are locally distinct and identifiable, but not consistently so. Contacts between the cyclic and marine members (combined) and the leached and collapsed members (combined) are difficult to identify reliably, both in surface and subsurface conditions (T. Small, oral commun., 2003). Similar uncertainties apply to the boundary between the grainstone member and the Kirschberg Evaporite Member, as well as the basal nodular and dolomitic members of the Kainer Formation. Much of the uncertainty in identifying boundaries is due to extensive and irregular post-depositional modification of the units. Hovorka (1996) further argues that the hydrostratigraphic-unit boundaries are indistinct because they are not truly stratigraphic contacts and may reflect lateral facies changes as well. Hovorka (1996) has documented numerous high-frequency upward-shoaling cycles (about 10 or 11) based on sedimentary fabric, fossils, and other factors within the Kainer and Person Formations. These sedimentological cycles produce repetitive and similar lithologic sequences throughout the section that make lithic correlation difficult, especially where stratigraphic context is limited.

All investigators seem to concur that the basal nodular member at the base of the Kainer Formation and the regional dense member at the base of the Person Formation are distinct, identifiable, and stratigraphically significant units (compare, for example, Maclay and Small, 1986, fig. 8, and Hovorka and others, 1996, fig. 23, interpretations of the Castle Hills well and surroundings). These units mark substantial increases in water depth related to sea-level rise at the time of deposition (Hovorka, 1996). 
Table 1. General lithologic and hydrologic characteristics of Edwards Group hydrostratigraphic units depicted in the 3-D model (based on Maclay and Small, 1986, and Stein and Ozuna, 1996).

\begin{tabular}{|c|c|c|c|c|}
\hline $\begin{array}{l}\text { Hydrostratigraphic unit } \\
\text { [zone abbreviation used in 3D } \\
\text { viewer is shown in brackets] }\end{array}$ & $\begin{array}{l}\text { Thickness } \\
\text { range } \\
\text { (feet) }\end{array}$ & Lithology & Permeability/porosity & Fractures \\
\hline $\begin{array}{l}\text { Upper confining } \\
\text { (Del Rio Clay and other units) } \\
\text { [confining_unit] }\end{array}$ & $0->500$ & $\begin{array}{l}\text { Claystone, mudstone, and thin shell } \\
\text { beds }\end{array}$ & Low to nil & Few, closed \\
\hline Georgetown Fm. [GTOWN] & about 20 & Marly limestone & Low/low & Few, closed \\
\hline $\begin{array}{l}\text { Cyclic+marine member } \\
\text { [CYMRN] }\end{array}$ & $80-90$ & $\begin{array}{l}\text { Thin-bedded packstone, grainstone and } \\
\text { mudstone }\end{array}$ & $\begin{array}{l}\text { Moderate to high matrix perm.; laterally extensive } \\
\text { cavernous zones; } 5-15 \% \text { porosity }\end{array}$ & Many, open \\
\hline $\begin{array}{l}\text { Leached+collapsed member } \\
\text { [LCCLP] }\end{array}$ & $70-90$ & $\begin{array}{l}\text { Massive crystalline limestone interbed- } \\
\text { ded with mudstone and grainstone; } \\
\text { collapse breccia common }\end{array}$ & $\begin{array}{l}\text { Moderate to high matrix perm.; laterally extensive } \\
\text { cavernous zones; } 5-20 \% \text { porosity }\end{array}$ & Many, open \\
\hline Regional dense member [RGDNS] & $20-24$ & Dense argillaceous mudstone & Low matrix perm.; $<5 \%$ porosity & Few, closed \\
\hline Grainstone member [GRNSTN] & $50-60$ & $\begin{array}{l}\text { Cross-bedded grainstone interbedded } \\
\text { with packstone and some mudstone }\end{array}$ & Moderate matrix perm.; $5-15 \%$ porosity & Few, open \\
\hline $\begin{array}{l}\text { Kirschberg Evaporite Member } \\
{[\mathrm{KSCH}]}\end{array}$ & $50-60$ & $\begin{array}{l}\text { Altered, crystalline limestone with } \\
\text { chalky mudstone and chert }\end{array}$ & $\begin{array}{l}\text { High matrix perm.; probable extensive caverns; } 5-25 \% \\
\text { porosity }\end{array}$ & Probably many, open \\
\hline Dolomitic member [DOLO] & $110-130$ & $\begin{array}{l}\text { Massively bedded grainstone to mud- } \\
\text { stone }\end{array}$ & Moderate matrix perm.; some caverns; $5-20 \%$ porosity & Many, open \\
\hline Basal nodular member [BSNOD] & $50-60$ & $\begin{array}{l}\text { Shaly, nodular limestone, mudstone, } \\
\text { and some grainstone }\end{array}$ & $\begin{array}{l}\text { Very low matrix perm.; large caves at surface; low } \\
\text { subsurface } \\
\text { permeability; }<10 \% \text { porosity }\end{array}$ & Few, open \\
\hline $\begin{array}{l}\text { Lower confining (Glen Rose } \\
\text { Limestone, etc.) [UGLRS] }\end{array}$ & $>350$ & $\begin{array}{l}\text { Thin-bedded limestone and marl; } \\
\text { persistent beds }\end{array}$ & Relatively impermeable & Moderate, closed \\
\hline
\end{tabular}


For the purpose of this modeling study, we elected to depict the eight hydrostratigraphic units of the Edwards aquifer, as defined by Maclay and Small (1986). This decision was mostly based on the practical consideration that numerous drill holes within the area had been logged and interpreted within this hydrostratigraphy (Small and Maclay, 1982), and that these units are recognized as useful by water management agencies in the area (J. Waugh, San Antonio Water System, oral commun., 2002). Our subsurface depiction of the aquifer structure is also consistent with the geologic mapping on the outcrop in this area (Stein and Ozuna, 1996). These hydrostratigraphic units and their general characteristics are summarized in table 1 .

The base of the Edwards aquifer is formed by the top of the Glen Rose Formation, which consists of several hundred feet of thin, alternating beds of dense limestone, dolomitic limestone, marl, and sparse evaporite deposits. The Glen Rose has little vertical permeability, limited lateral permeability along evaporite beds, and sparse fractures (Maclay and Small, 1986). It forms the regional lower confining unit beneath the Edwards aquifer.

The basal nodular member of the Kainer Formation consists of 50-60 ft of dense nodular, shaly limestone, mudstone, and grainstone. The unit has limited porosity and permeability, relatively few fractures, and generally behaves as a confining bed in the subsurface. Caves and conduits have been noted within this unit in the recharge zone where dissolution has occurred (Maclay and Small, 1986).

The dolomitic member of the Kainer Formation consists of 110-130 ft of dolomitized burrowed wackestone deposited in tidal and sub-tidal environments (Maclay, 1995). The overlying Kirschberg Evaporite Member of the Kainer Formation comprises 50-60 ft of tidal and supratidal limestone, dolomite, and evaporite deposits. The Kirschberg has extensive matrix and fracture porosity and highly permeable zones related to dissolution and collapse (Maclay and Small, 1986). The upper part of the Kainer Formation is described as the grainstone member and consists of 50-60 ft of grainstone, wackestone, and thin beds of marl. This member represents shallow-water lagoonal deposition under moderate to high-energy conditions; matrix porosity is locally significant and cavernous, and honeycombed zones are notable in the middle of the unit (Maclay and Small, 1986).

The basal hydrostratigraphic unit of the Person Formation is designated the regional dense member and consists of 20-24 ft of dense, argillaceous deep-water limestone; it forms a persistent confining bed within the Edwards aquifer. The overlying 70-90 ft consist of tidal and supradtidal limestone and dolomite packstone that are designated the (combined) leached and collapsed members due to widespread honeycomb porosity and collapse breccia (Maclay and Small, 1986; Hovorka and others, 1996). The topmost unit of the Person Formation is designated the (combined) cyclic and marine members, and they consist of 80-100 ft of reefal limestone and dolomitic grainstone and packstone, evaporite beds, and argillaceous limestone (Maclay and Small, 1986). This upper unit of the
Person Formation shows variable thickness and considerable porosity due to karst dissolution and brecciation related to late Early Cretaceous erosion (Maclay, 1995, table 3).

The Georgetown Formation forms the top of the Edwards aquifer and comprises $60 \mathrm{ft}$ or less of dense, marly limestone deposited under marine conditions (Maclay and Small, 1986). The Georgetown has low porosity and permeability and generally behaves as a confining bed in the section.

\section{Geologic Controls on Ground-water Flow}

At the regional scale, the stratified rock units of the Edwards aquifer dip gently toward the south and southeast at inclinations of a few tens of feet per mile, and only a bit more steeply than the inclination of the Gulf Coastal Plain between the Edwards Plateau and the Gulf of Mexico. One might expect regional ground water in the aquifer to flow south-southeastward toward the Gulf if this simple tilted stratigraphic section were the main control. However, flow patterns in the Edwards aquifer are strongly influenced by both the structure and evolution of the Balcones fault zone (Maclay and Small, 1986; Barker and others, 1994; Maclay, 1995).

Miocene uplift of the Edwards Plateau was accomplished by displacements across en echelon strands of the Balcones fault zone (fig. 3). These normal faults generally trend eastnortheast and chiefly show down-to-the-south offsets. Some shorter strands show down-to-the-north offset and form the south margins of small graben blocks in the complex fault zone.

Flow is strongly controlled by the trend of the Balcones fault zone for two reasons. First, fracturing and dissolution along all fault strands contributed to development of highpermeability ground-water flow zones (Maclay and Small, 1986; Maclay, 1995). Second, fault strands place hydrologically dissimilar parts of the aquifer side-by-side and therefore act as barriers or conduits for cross-fault flow, depending on amount of offset (Maclay and Small, 1986). Over time, faults have acted to divert southeast-directed down-dip flow toward the east-northeast where major springs discharge from the Edwards aquifer.

The average total thickness of rocks of the Edwards aquifer is about $500 \mathrm{ft}$ in northern Bexar County (Maclay and Small, 1986). If one excludes the basal nodular member from the bottom and the low-permeability Georgetown Formation from the top, the average effective thickness of the aquifer is roughly 420-430 ft. The aquifer is contained above and below by thick sections of relatively impermeable rock (Del Rio Clay through Navarro Group above, more than $800 \mathrm{ft}$ thick; Glen Rose Limestone below, about $900 \mathrm{ft}$ thick). Displacements across strands of the Balcones fault zone range from a few feet to about 1,000 ft. Thus, any fault offset of the Edwards aquifer places part of the permeable zone adjacent to less permeable rock and diminishes the effective thickness of the aquifer. For every $50 \mathrm{ft}$ of fault displacement, the aquifer thickness is reduced by about 10 percent (see Maclay, 1995, fig. 14, for schematic depiction of fault-offset effects). 
The formation of high-permeability zones took place over millions of years within the northern part of the Balcones fault zone. Leaching and dissolution of the dolomitic and evaporitic components did not occur in the southern, down-thrown blocks of the Balcones fault zone (Maclay and Small, 1986). In this part of the system, the Edwards Group and Georgetown Formation remain dolomitic and retain bedded evaporite deposits (Maclay and Small, 1986). Interstitial formation water is moderately to strongly saline compared to the fresh-water zone, and it is particularly enriched in chloride and sulfate anions. The practical down-dip limit of potable water in the Edwards aquifer system is marked by the arbitrarily defined threshold of 1,000 ppm total-dissolved-solids (Maclay and Small, 1986; Schultz, 1994). This concentration value marks the southern extent of the officially recognized Edwards aquifer.

\section{Sources of Data for the 3-D Geologic Framework}

We used a combination of subsurface and surface data to define the tops of recognized hydrostratigraphic units within the Edwards aquifer (fig. 4). The model area was defined around a set of 30 wells drilled by the U.S. Geological Survey (USGS) for the Edwards Aquifer Authority in 1998 to serve as monitoring wells in the recharge zone across northern Bexar County (L. Fahlquist, USGS-Austin, written commun., 2002). The subsurface data represent interpreted boundaries between hydrostratigraphic units and are based on examinations of cuttings and geophysical logs documented in several sources (Small and Maclay, 1982; Maclay and Small, 1983; Small, 1986). Additional subsurface data for the tops of formation-rank geologic units were obtained from Texas Water Development Board well records for the area (http: //wiiddev.twdb.state.tx.us/)

Surface altitude control for the tops of some hydrostratigraphic units was obtained by interpolation from standard USGS topographic maps (scale 1:24,000) and the mapped geologic contacts of Stein and Ozuna (1996) and other maps cited in the compilation of Collins (2000). These data points provided important information about the shape of the lower units in the 3-D geologic model in the area north of the main strands of the Balcones fault zone.

\section{Modeling Methodology}

EarthVision ${ }^{\mathrm{TM}}$ creates a mathematical construct to provide a three-dimensional representation of a surface defined by input scattered data. The software allows considerable discretion in the kinds of gridding and smoothing operations that are employed to generate this surface representation from any given set of input data. EarthVisionTM primarily uses a technique called "minimum surface-tension" gridding; details are beyond the scope of this report but are available from Dynamic Graphics, Inc., at http://www/dgi.com. This set of techniques has demonstrated considerable utility in generating reliable model representations of geologic surfaces that are defined by data that are irregularly distributed in space, as are most well- and outcrop-based observations.

EarthVision ${ }^{\mathrm{TM}}$ has the capability to accurately represent faulted geologic units in three dimensions, and that feature makes this software particularly suited for application to the Edwards aquifer system within the Balcones fault zone. Fault structure in the model was based principally on the mapped faults of Stein and Ozuna (1996). Significant faults were identified on the basis of mapped offset of hydrostratigraphic units, strike length, and general concurrence with mapped faults portrayed by Collins (2000). We ended up incorporating more than 25 faults and fault segments in the 3-D geologic model. Sense of offset was interpreted from the map relations and confirmed with staff of the USGS Water Resources Office in San Antonio. We made an arbitrary assumption that all faults are normal faults (based on the long-recognized extensional environment of the Balcones fault zone; Barker and others, 1994; Maclay, 1995; Collins, 2000), and we assigned a dip value of approximately 85 degrees to each fault.

The modeling process in EarthVision ${ }^{\mathrm{TM}}$ begins with the definition of the fault structure and the geologic horizons to be represented. In this case, the model horizons are defined as the tops of the hydrostratigraphic units bounding and within the Edwards aquifer system. All horizons are treated mathematically as depositional surfaces (even though some are recognized as regional disconformities; Barker and others, 1994) because the various hydrostratigraphic units are known to be present all across the San Marcos Platform area encompassed by the model (for example, Maclay, 1995). Thickness of individual units varies throughout the model as a result of variances in thickness values recorded in the input data from drill holes and mapped outcrop relations. We believe most of the thickness variances are real in the sense that they were based on objective criteria used by outcrop mappers and well$\log$ interpreters. Some of the variances, however, may reflect incomplete sections due to local faulting, thickness changes due to dissolution and collapse, or inherent uncertainties in picking some of the unit contacts from geophysical logs.

The deepest horizon in the model is the top of the Glen Rose Limestone, which also represents the base of the Edwards aquifer system. This horizon was well defined by drill-hole data across the model area and by outcrop data for the catchment zone north of the Balcones escarpment. We designated this "upper Glen Rose" horizon as a reference surface for the calculations because it was controlled by abundant data across the model volume. As a reference horizon, the "upper Glen Rose" surface influences the shape of all overlying horizons (tops of hydrostratigraphic units) and serves to help recreate the general "layer-cake" geometry of the units in this area.

The top horizon of each higher hydrostratigraphic unit was added to the model in subsequent calculations. These horizons were defined first on the basis of drill-hole altitude 


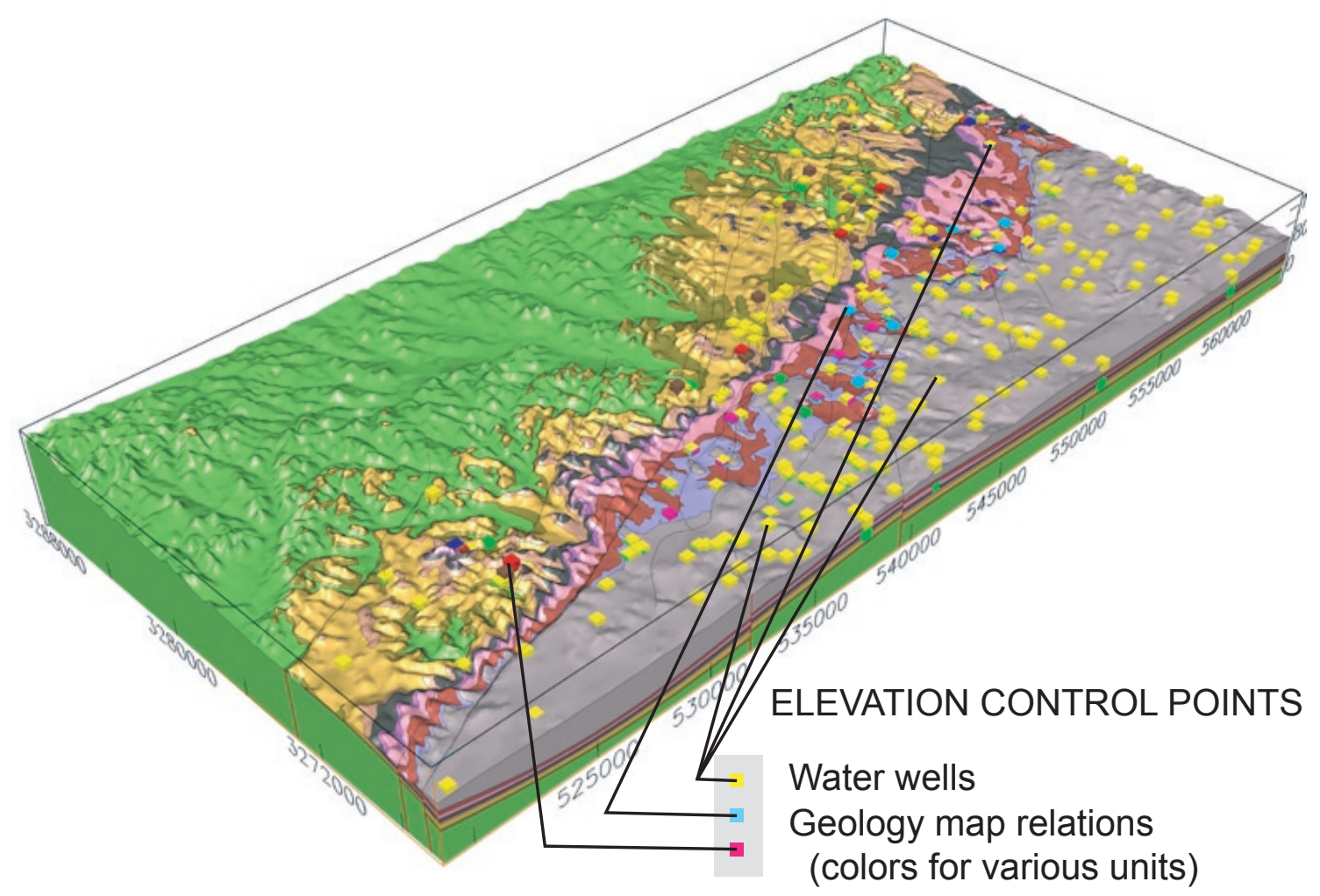

Figure 4. Overview (looking northeast) across the 3-D geologic model, showing distribution of control points used to construct and validate the model. Colors of the outcropping units are the same as those shown in figure 2. Numerical coordinates displayed along the base of the model are UTM (metric), Zone 14. Scale varies across the illustration due to perspective.

data, but they were further controlled by reference to the upper Glen Rose surface and, in many cases, to additional adjacent horizons. Trial and error was used in several iterations to adjust gridding and smoothing operations to achieve general continuity of adjacent hydrostratigraphic layers across the model volume. We felt this approach was justified because none of the units was known to pinch out against adjacent units across the San Marcos Platform (Maclay, 1995).

We used gridded data from USGS 30-meter Digital Elevation Model topographic datasets for the region to describe the top surface of the model. These data were used to define an upper clipping surface that truncated all surfaces deeper in the model and thus mimicked the intersection of topography with bedded geologic units. That part of the model volume above the top of the Georgetown Formation and below the topographic clipping surface is designated the "upper confining unit" in the model and consists of numerous hydrostratigraphic units that are not subdivided for this project.

Two of the model layers were modeled as units of constant thickness, in part to simplify the model calculations. The drill-hole data and outcrop mapping indicated that the regional dense member could be reliably represented as a layer about $22 \mathrm{ft}$ thick across the model volume. Similar considerations allowed us to model the cyclic and marine members (combined) as a layer about $53 \mathrm{ft}$ thick.

\section{Evaluation of Data Quality}

Prior to using the drill-hole data for 3-D modeling purposes, we performed some 2-D analysis of calculated isopach thickness values for all of the hydrostratigraphic units. Longstanding descriptions of these units from mapping and subsurface interpretations led us to expect that we would find relatively minor variations in unit thickness across northern Bexar County (Rose, 1972; Maclay and Small, 1983, 1986; Barker and others, 1994). The data showed otherwise. Variations of more than 50 percent (above or below) mean values were present in scattered locations for several of the hydrostratigraphic units.

Several of the conspicuous thickness anomalies were readily resolved as inaccuracies or inconsistencies in stratigraphic picks for drill holes. In a given well record, for example, an anomalously thick interval of a particular unit was paired with an anomalously thin interval of an adjacent unit. In most of these cases, the original geophysical log of the specific interval in the well was found to be ambiguous regarding the contact between the two adjacent units. Alternatively, the geophysical log provided other evidence for a unit boundary at an altitude more consistent with unit thicknesses of nearby drill holes. Adjustments were made in the input data for these wells based on the judgment and reinterpretations of staff of the USGS Water Resources office in San Antonio (T. Small, A. Clark, and J. Faith, written commun., 2003). 


\section{Interactive Viewing of the 3-D Model}

The completed 3-D faulted hydrostratigraphic model of northern Bexar County is included with this report in the form of a user-explorable and user-manipulatable volumetric graphic file. Instructions included in the "readme" file and the "Quick Help" file for the EarthVision ${ }^{\mathrm{TM}}$ 3-D viewer should be consulted before launching the viewer for this model. More detailed instruction and reference are contained in the PDF file, which is the full technical manual for the 3-D viewer.

This viewer package has been processed by Dynamic Graphics, Inc., so that most functions of the 3-D viewer are available to the user on several computer platforms. The viewer only works on this version of the 3-D faulted hydrostratigraphic model for northern Bexar County. USGS has paid a one-time fee to Dynamic Graphics, Inc., for this service and for the right to unlimited distribution of this report and the encrypted 3-D viewer.

The user is allowed to manipulate the model volume in 3D space by rotating, zooming, and panning at will. The model may be sliced perpendicular to the $x, y$, or $z$ axes at pre-set spacings or at any position selected by the user. Model layers (designated "zones" in EarthVision ${ }^{\mathrm{TM}}$ ) may be activated to "display" or "not display" at user discretion so that tops of each hydrostratigraphic unit may be examined in detail, and fault offsets of particular units may be displayed and analyzed. Individual fault blocks may be identified and activated to "display" or "not display" at user discretion; this process allows the user to explore fault structure in detailed 3-D renderings.

The user also has tools to display any or all of the drillhole and outcrop data that were used in generating this faulted 3-D geologic model. Scattered data for any particular geologic horizon may be displayed, or all of the data may be shown for all drill holes. All data displayed within the model can be identified; clicking the right mouse-button on any data point will cause a box to display with the $x, y$, and $z$ coordinates of the point, along with its well identifier.

\section{Conclusions}

This faulted hydrostratigraphic model of the Edwards aquifer system in northern Bexar County shows the geometric relationships of faults and layered units in detail. It is based on interpreted drill-hole logs and mapped relationships that were developed by the USGS over the last decade. This model, distributed with a fully functional 3-D viewer, allows users to explore the model geometry and evaluate the consistency of the data that were used in its construction.

\section{Getting to the 3-D model}

The 3-D geologic model and the software for the 3-D viewer are all contained on this CD-ROM. To open the viewer and explore the model, open the file "readme1.txt" and follow the directions for the computer system you are using. Data files, help files, and technical manuals are also contained on this CD-ROM.

\section{References}

Abbott, P.L., 1975, On the hydrology of the Edwards limestone, south-central Texas: Journal of Hydrology, v. 24, p. 251-269.

Barker, R.A., Bush, P.W., and Baker, E.T.J., 1994, Geologic history and hydrogeologic setting of the Edwards-Trinity aquifer system, west-central Texas: U.S. Geological Survey Water Resources Investigations Report 94-4039, 51 p.

Collins, E.W., 2000, Geologic map of the New Braunfels, Texas, $30 \times 60$ minute quadrangle-Geologic framework of an urban-growth corridor along the Edwards aquifer, southcentral Texas: The University of Texas at Austin, Bureau of Economic Geology Miscellaneous Map No. 39, scale 1: $100,000,28$ p.

Hovorka, S.D., 1996, High-frequency cyclicity during eustatic sea-level rise: Edwards Group of the Balcones Fault Zone: Gulf Coast Association of Geological Societies Transactions, v. 46, p. 179-184.

Hovorka, S.D., Dutton, A.R., Ruppel, S.C., and Yeh, J.S., 1996, Edwards aquifer ground-water resources: Geologic controls on porosity development in platform carbonates, south Texas: The University of Texas at Austin, Bureau of Economic Geology Report of Investigations No. 238, 75 p.

Hovorka, S.D., Mace, R.E., and Collins, E.W., 1998, Permeability structure of the Edwards aquifer, south Texas-Implications for aquifer management: The University of Texas at Austin, Bureau of Economic Geology Report of Investigations No. 250, 55 p.

Maclay, R.W., 1995, Geology and hydrology of the Edwards aquifer in the San Antonio area, Texas: U.S. Geological Survey Water Resources Investigations Report 95-4186, 64 p.

Maclay, R.W., and Small, T.A., 1983, Hydrostratigraphic subdivisions and fault barriers of the Edwards Aquifer, South-Central Texas, U.S.A.: Journal of Hydrology, v. 61, p. 127-146.

Maclay, R.W., and Small, T.A., 1986, Carbonate geology and hydrology of the Edwards aquifer in the San Antonio area, Texas: Texas Water Development Board Report 296, 90 p.

Rose, P.R., 1972, Edwards Group, surface and subsurface, Central Texas: University of Texas at Austin, Bureau of Economic Geology Report of Investigations No. 74, 198 p.

Schultz, A.L., 1994, 1994 review and update of the position of the Edwards aquifer freshwater/saline-water interface from Uvalde to Kyle, Texas: Edwards Underground Water District Report 94-05, 31 p.

Sharp, J.M.J., and Banner, J.L., 1997, The Edwards Aquifer: A resource in conflict: GSA Today, v. 7, no. 8, p. 1-9. 
Slattery, R.N., and Brown, D.S., 1999, Recharge to and discharge from the Edwards Aquifer in the San Antonio area, Texas, 1998: U.S. Geological Survey Fact Sheet 99-01, 4 p.

Small, T.A., 1984, Identification and tabulation of geological contacts in the Edwards aquifer, San Antonio area, Texas: U.S. Geological Survey, Open-File Report OF 84-0075, 68 p.

Small, T.A., 1986, Hydrogeologic sections of the Edwards aquifer and its confining units in the San Antonio area, Texas: U.S. Geological Survey Water-Resources Investigations Report 85-4259, 52 p.
Small, T.A., and Maclay, R.W., 1982, Test-hole data for the Edwards aquifer in the San Antonio area, Texas: Texas Department of Water Resources LP-171, 153 p.

Stein, W.G., and Ozuna, G.B., 1996, Geologic framework and hydrogeologic characteristics of the Edwards aquifer recharge zone, Bexar County, Texas: U.S. Geological Survey Water-Resources Investigations Report 95-4030, 8 p.

Texas Water Development Board, 2001, Ground water data system: Records of wells, springs, and test holes: Texas Water Development Board Web site accessed 20 October 2004 at URL http://www.twdb.state.tx.us/data/waterwell/ well_info.asp. 